\title{
Obituary
}

\section{Kenneth Shirley Smith}

Kenneth Shirley Smith died on 29 January 1987. He was born in 1900 and pursued a long and distinguished career in cardiology. He was a senior scholar at the Middlesex Hospital Medical School, was awarded a BSc with first class honours in 1923, and qualified $\mathrm{MB} \mathrm{BS}$ in 1927 . He proceeded to MRCP in 1927 and an MD in 1929. He was elected a fellow of the Royal College of Physicians in 1933. After house appointments he became medical registrar at the Middlesex Hospital and then resident medical officer at the National Heart Hospital in 1927.

Subsequently he was appointed consultant physician to Charing Cross Hospital, the London Chest Hospital, and the Samaritan Hospital for Women. He served in the Royal Army Medical Corps during the Second World War in the First Army in North Africa and later with the Central Mediterranean Force in Italy, Greece, and Austria, retiring with the rank of Colonel. He was Gold Staff Officer at the coronation of King George VI.

After the war, Shirley Smith steadily built up his reputation in cardiology. His work (with Max Zoob) on the use of pressor agents in the treatment of shock in myocardial infarction provoked interest and marked a new approach in the use of sympathomimetic drugs in cardiac crises. His interests in cardiology centred mainly on ischaemic heart disease and he published papers on electrocardiography in minor coronary thromboses and on various forms of angina.

Shirley Smith preceded, because of his age, the introduction and explosive onslaught of catheterisation and all that it brought with it. Nevertheless, he continued to maintain a high degree of expertise and a lively interest in all forms of cardiovascular disease. His organising ability was recognised by his appointment as secretary of the First European Congress of Cardiology which was held in London in 1952 under the presidency of the late Sir John Parkinson. The success of this congress, which was a pioneering event, was generally regarded as being due largely to the efficiency and application of Shirley Smith.

But Shirley Smith's principal fame came from his able editorship of the British Heart Journal. Starting as associate editor, he provided a perfect alliance with the editor, the late Dr Maurice Campbell, with

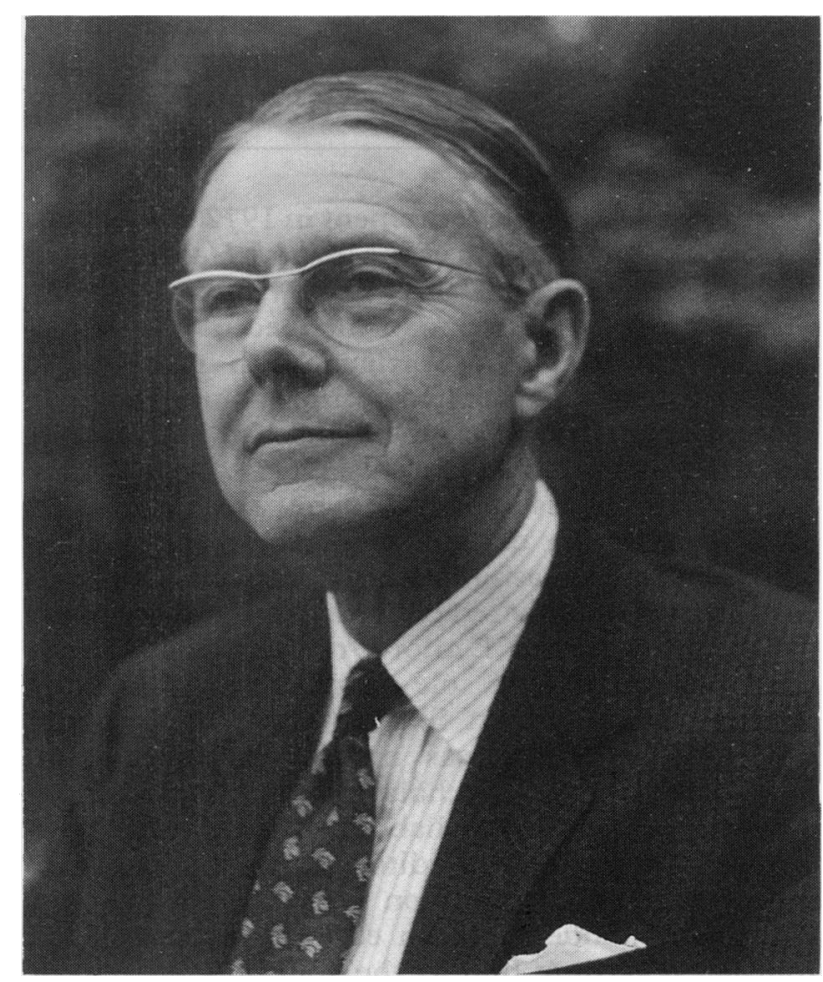

whom he developed a deep and abiding friendship and whom he served with great loyalty. Together they forged a journal of high merit which gained and still holds an outstanding international reputation. Eventually he succeeded to the editorship. He was an excellent editor: calm, efficient, and hardworking. He held firm views about how the journal should be run and though his attitudes may have occasionally appeared somewhat rigid, his rules of procedure and high standards of scientific merit, writing, composition, and management provided a firm base for the journal at a time when the advancing tide of cardiology was sweeping all before it. His insistence on a high standard of English made him scornful of pointless prolixity and high sounding phrases of little literary merit and dubious value.

When the time came for him to retire on the grounds of age from the National Health Service he spared no pains to see that every possible encouragement and practical help was given to his successor.

His career was enhanced by his election as presi- 
dent of the British Cardiac Society in 1964.

Kenneth Shirley Smith was an extremely courteous person of gentle mien with a quiet and quizzical sense of humour. His sympathetic and unassuming manner sometimes misled acquaintances into thinking him dull or colourless but this was not so; within the gentle carapace of courtesy lay a strand of steel. He could be determined and forceful. His strength of character lay in his ability to act decisively and firmly without losing his friendl迹 diplomatic approach.

In the later part of his active career he bore the fatal illness of his wife with great fortitude and courage.

Shirley Smith's contributions to cardiology were numerous, and the more notable because they were achieved in low key without fuss or excitement.

J F Goodwine
On the occasion of the retirement in 1972 of Kenneth Shirley Smith as editor of the British Heart Journal Walter Somerville, his successor, wrote:

... With the production of the December issue of the Journal, Kenneth Shirley Smith vacated the editorial chair which he had occupied since 1959. He succeeded Maurice Campbell who had been Editor since the birth of the Journal in 1938. By the time Shirley Smith assumed office he was thoroughly familiar with the distinctive genre of the Journal which had been fashioned by Campbell and Evan Bedford who had shared editorial responsibilities for the first ten years. Bedford retired in 1948 and Campbell was left in sole charge. One of his first actions was to appoint Shirley Smith as Associate Editor. The choice was natural and successful. Shirley Smith was of scholarly inclination, and for the next decade collaborated happily with Campbell's demanding editorial requirements. He expressed his admiration and gratitude for Campbell's influence in an editorial tribute in the Journal, regarding him as the Journal's progenitor and formative influence.

In the 14 years of his reign, Shirley Smith continued the evolutionary process, imposing his strong and sensitive policies on the Journal's person $\vec{\omega}$ ality. He was firm in his rejection of ambiguity in expression and inaccuracy, in uncovering false claims to originality, in rating papers according tơ their scientific importance, and in maintaining ant unimpeachable ethical standard. His artistic sensi tivity was reflected in his concern for basic standards of presentation. He was never disturbed by the lack of a high literary style; a writer's way of expressing himself was his own business, but he was always required to make his meaning clear and with as few. words as possible consistent with this objective $\bigodot_{\infty}^{\bullet}$ Otherwise Shirley Smith's only intrusion into an author's choice of words was his implacable distast of certain prevalent clichés....

The Journal flourished under Shirley Smith's guidance: in the course of 14 years the number of pages in each volume more than doubled, the Journa 1 advanced to monthly publication (initially quar $\neq$ terly), and the circulation increased by more than $7 \frac{3}{3}$ per cent....

Techniques of communication will change in time and we hope to play our proper part in evolving them. Meanwhile we ... are grateful for the pros perous order in which he left his charge. 